\title{
The Nitrogen Heterocycle Content of Meteorites and Their Significance for the Origin of Life
}

\author{
Zita Martins \\ Centro de Química-Física Molecular-Institute of Nanoscience and Nanotechnology (CQFM-IN) and Institute for \\ Bioengineering and Biosciences (iBB), Departamento de Engenharia Química, Instituto Superior Técnico (IST), \\ Universidade de Lisboa, 1049-001 Lisboa, Portugal; zita.martins@tecnico.ulisboa.pt \\ Received: 30 May 2018; Accepted: 10 July 2018; Published: 11 July 2018

\begin{abstract}
Carbonaceous chondrites are very primitive meteorites that are rich in carbon. They contain many soluble organic compounds, including nitrogen heterocycles. These play a crucial role in present-day living organisms as they are components of the genetic material and of the co-factors of enzymes. This review outlines the nitrogen heterocycle content of carbonaceous meteorites. The potential mechanisms of formation of these molecules are also described. Measurements of the compound-specific carbon and hydrogen isotopic compositions are mentioned as a way of establishing the origin of the nitrogen heterocycles detected in meteorites.
\end{abstract}

Keywords: nitrogen heterocycles; meteorites; life; prebiotic chemistry

\section{Introduction}

Meteorites are extraterrestrial objects originating from comets or asteroids that survive the passage through the Earth's atmosphere and impact the Earth's surface. They are named after the town or geographic feature in which they are found. The names of Antarctic meteorites are followed by a number, in which the first two digits correspond to the year the meteorite was found, and the last three digits correspond to the specimen number. Around $86 \%$ of all meteorites that fall to the Earth are chondrites. Their parent bodies have not experienced melting, and they are named after the millimeter-sized spherules (i.e., chondrules) that they contain. The parent bodies of the remaining $14 \%$ of meteorites that fall to the Earth have experienced melting and differentiation [1]. Chondrites can be divided into ordinary $(\mathrm{O})$, enstatite $(\mathrm{E})$, carbonaceous $(\mathrm{C})$, Rumuruti $(\mathrm{R})$, and Kakangari $(\mathrm{K})$ chondrites, with the ordinary, enstatite, and carbonaceous chondrites further divided into different groups according to their mineralogy and bulk chemical composition [1-3]. Carbonaceous chondrites are the most primitive meteorites because their bulk chemical compositions match that of the solar photosphere (except for the gaseous elements, e.g., H, He, etc.) more closely than any other class of chondrites [4]. The division of the carbonaceous chondrites into groups include the ones named after its type specimen (CI, CM, CK, CO, CR, CV), some unusual ones that have been affected by impact processes ( $\mathrm{CH}$ and $\mathrm{CB}$ ), and several ungrouped members [5]. They are further grouped into petrographic types (ranging from 1 to 6) depending on the intensity of thermal metamorphism or aqueous alteration on their parent bodies. Thermal metamorphism is the adjustment of the minerals due to the increased temperatures in the meteorite parent body, while aqueous alteration is the modification of the original minerals into a new assemblage of minerals, due to the reaction with water at low temperature in the meteorite parent body. A petrologic type from 3 to 1 indicates increasing aqueous alteration, while a petrologic type from 3 to 6 indicates increasing thermal metamorphism [6,7]. These processes may influence the chemical compositions of carbonaceous chondrites [7-9]. Carbonaceous chondrites have high carbon content ( 3.5 wt. \%) [10], which may be present in different forms, including organic 
matter [11-13]. More than $70 \%$ of this organic matter is in the solvent-insoluble form [14-16], while the remaining $30 \%$ is composed of several solvent-soluble organic compounds [17-19].

Nitrogen heterocycles, i.e., cyclic compounds that have at least one nitrogen atom along with carbon atoms as members of their rings, have been detected in the solvent-soluble organic fraction of carbonaceous chondrites. The nitrogen heterocycles detected in carbonaceous meteorites include pyridine carboxylic acids, diketopiperazine, hydantoins, purines, pyrimidines, triazines, pyridines, quinolines, carboxylactams, lactams, lactims, and the amino acid proline. Some of these compounds may have been directly involved in primitive biological systems, as in present-day nitrogen heterocycles are part of the co-factors of several enzymes as well as of genetic material (Ribonucleic acid (RNA) and Deoxyribonucleic acid (DNA)) [20]. The exogenous delivery of these meteoritic molecules between 4.56 to 3.8 billion years ago may have contributed to the inventory of compounds from which life may have emerged between 3.8 to 3.5 billion years ago [21-32]. Therefore, it is important to determine which nitrogen heterocycles are present in carbonaceous meteorites, which ones are indigenous, and what were their formation mechanisms. Measurement of the compound-specific carbon, hydrogen, or nitrogen isotopic compositions are usually used to determine if organic compounds detected in carbonaceous chondrites are indigenous or terrestrial contamination.

$$
\delta(\%)=\frac{\left(R_{\text {sample }}-R_{\text {standard }}\right)}{R_{\text {standard }}} \times 1000
$$

The stable isotope compositions are given in $\delta$ values (\%), where $R$ represents $\mathrm{D} /{ }^{1} \mathrm{H}$ for hydrogen, ${ }^{13} \mathrm{C} /{ }^{12} \mathrm{C}$ for carbon, or ${ }^{15} \mathrm{~N} /{ }^{14} \mathrm{~N}$ for nitrogen. The following standards are used: Vienna standard mean ocean water (VSMOW) for hydrogen, Vienna Pee Dee Belemnite (VPDB) for carbon, and atmospheric nitrogen for nitrogen. Indigenous organic compounds are enriched in $\mathrm{D},{ }^{13} \mathrm{C}$, and ${ }^{15} \mathrm{~N}$ (e.g., [17,33-35]).

Meteoritic soluble organic compounds are thought to be formed by different processes: low temperature reactions in the interstellar medium (supported by $\mathrm{D}$ and ${ }^{15} \mathrm{~N}$ enrichments [36-41]) and subsequent meteorite parent body accretion, aqueous alteration in the meteorite parent (i.e., melting of ice in the asteroid due to heating from the decay of several short-lived radionuclides, such as $\left.{ }^{26} \mathrm{Al}[42]\right)$, or a combination of these two mechanisms [17,41]. This manuscript reviews the nitrogen heterocycle content of carbonaceous meteorites and their formation mechanisms.

\section{Inventory of Meteoritic $N$-Heterocycles}

\subsection{Pyridine Carboxylic Acids}

Pyridine monocarboxylic acids have been detected in several carbonaceous chondrites [43-46]. They were first detected in Tagish Lake (C2-ungrouped) and Murchison (CM2), with total abundances of 7.5 and $>7$ parts-per-million (ppm), respectively [43]. Individual pyridine monocarboxylic acids present in the water extracts of these two meteorites included nicotinic acid (3-pyridinecarboxylic acid) and its two isomers (2-pyridinecarboxylic acid and 4-pyridinecarboxylic acid (Figure 1, structures A1-A3), and at least 12 methyl- and dimethyl-homologs [17]. Some of these compounds were found to be extra-terrestrial, as shown by the high positive values of $\delta^{13} \mathrm{C}=+20.3 \% 0 \pm 1.7$ and $\delta \mathrm{D}=+129 \pm 1 \%$ measured for nicotinic acid in Murchison [44,45]. A value of $\delta^{13} \mathrm{C}=+20.3 \pm 1.2 \%$ o was determined for one of the methyl homologues of nicotinic acid in Murchison (CM2), and a value of $\delta \mathrm{D}=+621 \pm 43 \%$ o was measured in Murray (CM2) (Table 1) [44,45]. Eight Antarctic CM2 meteorites were further analysed for pyridine monocarboxylic acids: Allan Hills (ALH) 85013, Dominion Range (DOM) 03183, DOM 08003, Elephant Moraine (EET) 96016, LaPaz Ice Field (LAP) 02333, LAP 02336, Lewis Cliff (LEW) 85311, and Wisconsin Range (WIS) 91600. The three structural isomers were present in formic acid extracts of all these meteorites (Table 2) [46]. In addition, pyridine dicarboxylic acids (3,4-pyridinedicarboxylic acid, 2,5-pyridinedicarboxylic acid, and 3,5-pyridinedicarboxylic acid) were unambiguously identified in multiple of those meteorite extracts [46] (Figure 1, structures A4-A6). 
A. pyridine carboxylic acids<smiles>O=C(O)c1ccccn1</smiles>

A1

2-pyridinecarboxylic acid (picolinic acid)<smiles>O=C(O)c1ccncc1C(=O)O</smiles>

A4

3,4-pyridinedicarboxylic acid

B. Diketopiperazine<smiles>O=C1CNC(=O)CN1</smiles>

2,5-Piperazinedione

(Cyclo(glycylglycine))

\section{Hydantoins}

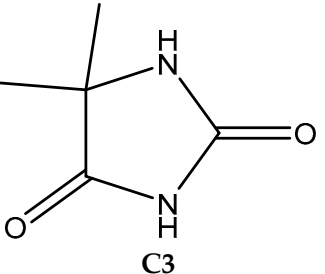

5,5-Dimethyl-2,4-

imidazolidinedione

(5,5-Dimethylhydantoin)<smiles>O=C(O)CC1NC(=O)NC1=O</smiles>

(2,5-Dioxo-4-

imidazolidinyl)acetic acid (5-Carboxymethylhydantoin)<smiles>O=C(O)c1cccnc1</smiles>

A2

3-pyridinecarboxylic acid (nicotinic acid)<smiles>O=C(O)c1ccc(C(=O)O)nc1</smiles>

A5

2,5-pyridinedicarboxylic acid

\section{Hydantoins}

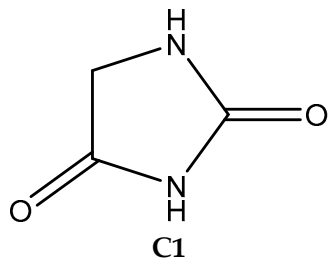

2,4-Imidazolidinedione (Hydantoin)<smiles>O=C(O)c1ccncc1</smiles>

A3

4-pyridinecarboxylic acid (isonicotinic acid)<smiles></smiles>

3,5-pyridinedicarboxylic acid 


\section{Purines}<smiles>c1ncc2[nH]cnc2n1</smiles>

Purine<smiles>Nc1ncnc2[nH]cnc12</smiles>

Adenine<smiles>Nc1nc(N)c2nc[nH]c2n1</smiles>

Purine-2,6-diamine (2,6-Diaminopurine)<smiles>Nc1nc2[nH]cnc2c(=O)[nH]1</smiles>

Guanine<smiles>Nc1nc2c(N)ncnc2[nH]1</smiles>

Purine-6,8-diamine (8-Aminoadenine)<smiles>O=c1[nH]cnc2[nH]cnc12</smiles>

1,9-Dihydro-purine-6-one (Hypoxanthine)<smiles>O=c1[nH]c(=O)c2[nH]cnc2[nH]1</smiles>

3,7-Dihydropurine-2,6-dione

E. Pyrimidines<smiles>O=c1cc[nH]c(=O)[nH]1</smiles>

E1<smiles>Oc1ccncn1</smiles>

E2

4-Hydroxypyrimidine

2,4(1H,3H)-Pyrimidinedione (Uracil)

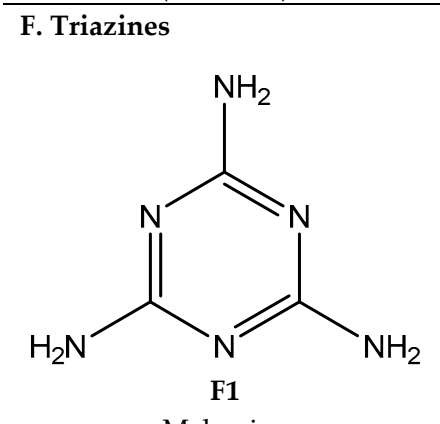

Melamine<smiles>Nc1nc(=O)nc(N)[nH]1</smiles>

Ammeline<smiles>Oc1nc(O)nc(O)n1</smiles>

Cyanuric acid

Figure 1. Cont. 


\section{G. Pyridine}<smiles>Cc1cc(C)nc(C)c1</smiles>

2,4,6-trimethylpyridine (Collidine)

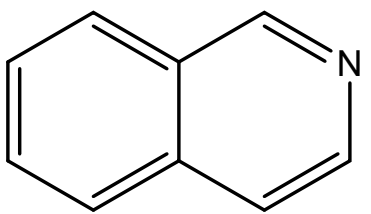

H3

Isoquinoline
H. Quinoline<smiles>c1ccc2ncccc2c1</smiles>

H1

Quinoline<smiles>Cc1ccc2ccccc2n1</smiles>

2-methylquinoline<smiles>c1ccc2cnccc2c1</smiles>

$\mathrm{H} 2$

Isoquinoline<smiles>Cc1ccnc2ccccc12</smiles>

H5

4-methylquinoline<smiles>O=C1CCC(C(=O)O)N1</smiles>

I1

5-Oxoproline

(Pyroglutamic acid)

\section{Carboxylactams}

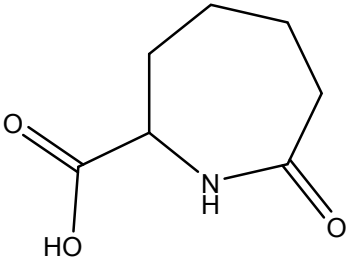

I4

7-Oxo-2-azepanecarboxylic acid

\section{J. Lactams}<smiles>O=C1CCCCN1</smiles>

J3

2-Piperidinone ( $\delta$-valerolactam)<smiles>CC1(C(=O)O)CCC(=O)N1</smiles>

2-Methyl-5-oxoproline J. Lactams

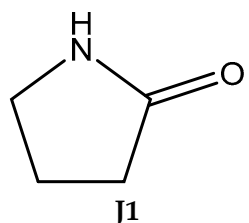

2-Pyrrolidinone

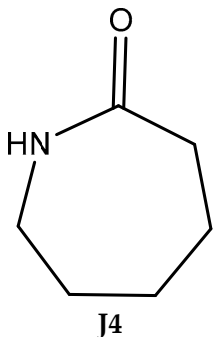

2-Azepanone

( $\varepsilon$-caprolactam)<smiles>O=C1CCCC(C(=O)O)N1</smiles>

I3

6-Oxo-2-piperidinecarboxylic acid (6-oxopipecolic acid)

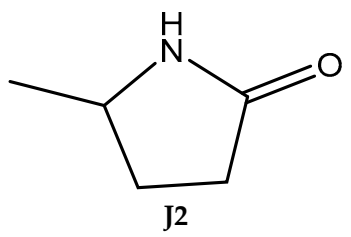

5-Methyl -2-pyrrolidinone $(\gamma$-Valerolactam)

Figure 1. Cont.

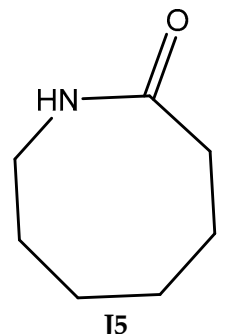

2-Azocanone $(\omega$-Heptalactam) 


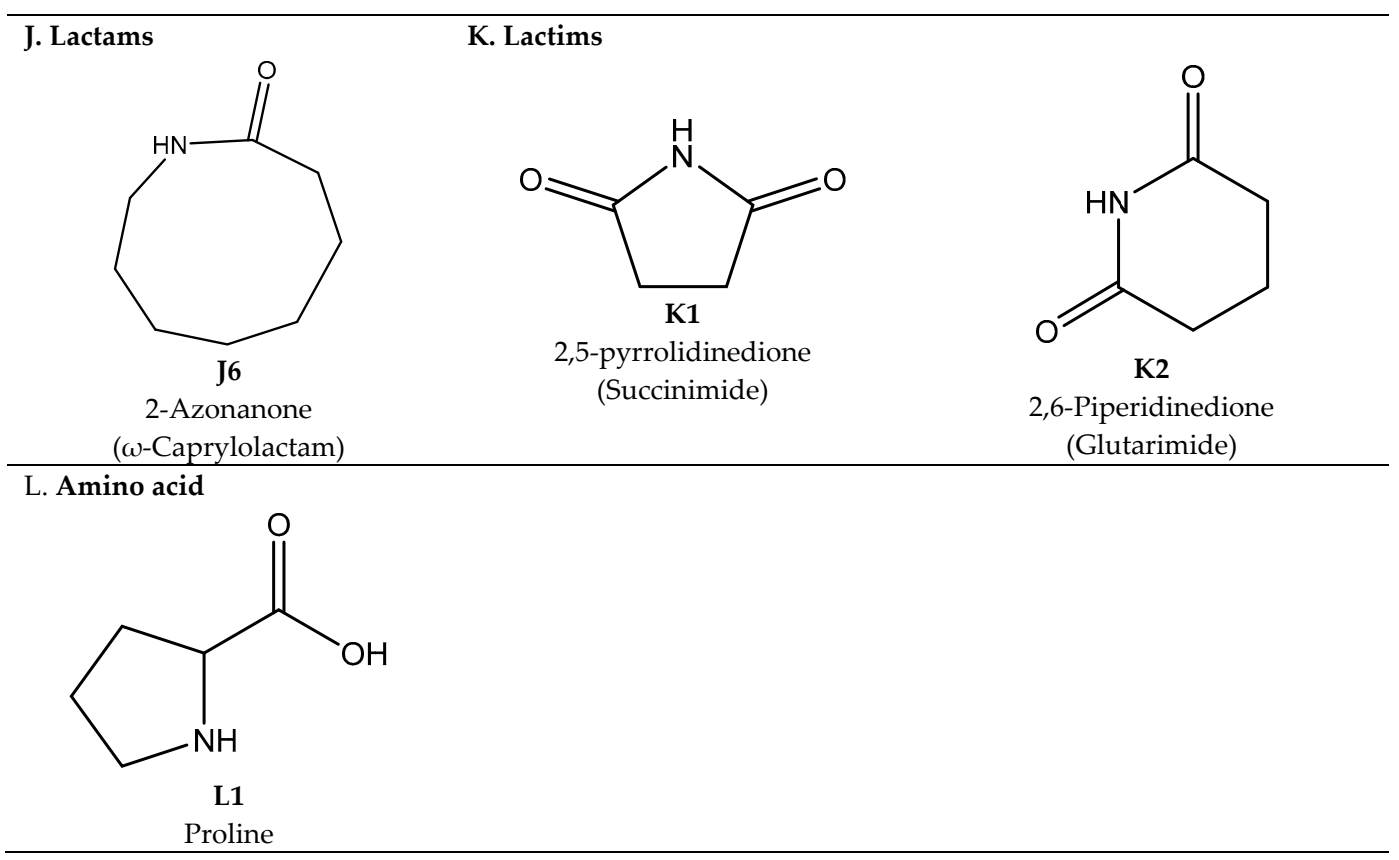

Figure 1. The structure and the International Union of Pure and Applied Chemistry (IUPAC) name (and other commonly known name) of the nitrogen heterocycles detected in carbonaceous chondrites. Compounds include pyridine carboxylic acids (A1 to A6), a diketopiperazine (B1), hydantoins (C1 to C7), purines (D1 to D7), pyrimidines (E1 and E2), triazines (F1 to F3), pyridine (G1), quinolines (H1 to H3), carboxylactams (I1 to I4), lactams (J1 to J6), lactims (K1 to K2), and amino acid proline (L1).

Table 1. Compound specific stable isotope composition $(\%)$ of individual pyridine carboxylic acids in Murchison and Murray [44,45].

\begin{tabular}{ccccc}
\hline & \multicolumn{2}{c}{ Murchison } & \multicolumn{2}{c}{ Murray } \\
\cline { 2 - 5 } & $\delta \mathrm{D}$ & $\boldsymbol{\delta}^{\mathbf{1 3}} \mathbf{C}$ & $\delta \mathrm{D}$ & $\boldsymbol{\delta}^{\mathbf{1 3}} \mathbf{C}$ \\
\hline Nicotinic acid & $+129 \pm 1$ & $+20.3 \pm 1.7$ & - & - \\
Nicotinic methyl homologue & - & $+20.3 \pm 1.2$ & $+621 \pm 43$ & - \\
\hline
\end{tabular}

Table 2. The abundances (ppb) of pyridine carboxylic acids in the formic acid extracts of carbonaceous meteorites [46].

\begin{tabular}{ccccccccc}
\hline & WIS 91600 & DOM 03183 & DOM 08003 & ALH 85013 & EET 96016 & LAP 02333 & LAP 02336 & LEW 85311 \\
\hline Picolinic Acid & $25.1 \pm 2$ & $70.2 \pm 7$ & $482.2 \pm 48$ & $98.8 \pm 10$ & $322.0 \pm 32$ & $197.1 \pm 20$ & $318.4 \pm 32$ & $510.7 \pm 51$ \\
Nicotinic Acid & $96.3 \pm 10$ & $121.9 \pm 12$ & $221.0 \pm 22$ & $139.6 \pm 14$ & $265.1 \pm 26$ & $246.8 \pm 25$ & $332.1 \pm 33$ & $571.8 \pm 57$ \\
Isonicotinic Acid & $42.0 \pm 42$ & $70.8 \pm 7$ & $153.7 \pm 15$ & $67.4 \pm 7$ & $116.7 \pm 12$ & $161.5 \pm 16$ & $256.9 \pm 26$ & $294.1 \pm 29$ \\
\hline
\end{tabular}

Synthesis of Pyridine Carboxylic Acids

Aqueous alteration in the meteorite parent body seems to influence the synthesis of pyridine carboxylic acids, with a decrease of their abundances with increasing aqueous alteration, i.e., aqueous alteration may have had a destructive effect on these compounds [46]. In addition, it was proposed that the oxidation of alkylpyridines would give pyridine carboxylic acids [47]. Although to date no pyridine carboxylic acids or their potential precursors (e.g., pyridine) have been detected in the interstellar medium, they may have been formed by radiation of icy interstellar grains. To test this, a 1:1 ice mixture of pyridine and $\mathrm{CO}_{2}$ was proton-irradiated [46]. Pyridine monocarboxylic acids were later identified in the corresponding non-volatile residue, with distributions similar to the ones detected in carbonaceous meteorites, which suggested that interstellar chemistry may have contributed to the 
formation of meteoritic pyridine carboxylic acids. However, it was pointed out that more realistic interstellar ice compositions should be tested before drawing a conclusive remark [46].

\subsection{Diketopiperazine and Hydantoins}

2,5-Piperazinedione (cyclo(Gly-Gly)) was the only diketopiperazine detected in carbonaceous chondrites (Figure 1, structure B1). It was present in the Yamato-791198 (CM2) and Murchison (CM2) meteorites at the concentrations of 2.1 and 2.6 parts-per-billion (ppb), respectively (Table 3) [48]. Hydantoins were also detected in the same meteorite extracts, with concentrations ranging from 1.0 to $6.5 \mathrm{ppb}$ in Yamato-791198, and from 0.9 to $11.9 \mathrm{ppb}$ in Murchison (Table 3) [48]. Detected compounds included hydantoin, 5-methylhydantoin, 5,5-dimethylhydantoin, 5-ethylhydantoin, 5-ethyl-5-methylhydantoin, 5-carboxymethylhydantoin, and 5-(2-carboxyethyl)hydantoin (Figure 1, structures C1-C7). Some of these were previously detected in Murchison, but their concentration was not determined [49].

Table 3. Concentration (ppb) of a piperazine and the hydantoins in Yamato-791198 and Murchison [48].

\begin{tabular}{ccc}
\hline & Yamato-791198 & Murchison \\
\hline Cyclo(glycylglycine) & 2.1 & 2.6 \\
Hydantoin & 6.5 & 7.3 \\
5-Methylhydantoin & 5.5 & 11.9 \\
5,5-Dimethylhydantoin & 5.6 & 9.0 \\
5-Ethylhydantoin & 1.0 & 1.5 \\
5-Ethyl-5-methylhydantoin & 3.4 & 6.7 \\
5-Carboxymethylhydantoin & n.d. & 0.9 \\
5-(2-Carboxyethyl)hydantoin & n.d. & 1.4 \\
\hline n.d.-Not detected above $0.9 \mathrm{ppb}$. \\
\end{tabular}

Synthesis of Diketopiperazine and Hydantoins

The only detected diketopiperazine (2,5-piperazinedione) in carbonaceous meteorites may have been formed by oligomerization of amino acids via drying-wetting cycles in the presence of inorganic materials (e.g., clay minerals) [50-53]. Glycine is more reactive than other amino acids to form dipeptides by oligomerization on the surface of a clay mineral, which could explain why 2,5-piperazinedione (cyclo(Gly-Gly)) was the only detected diketopiperazine in meteorites [48,51]. Hydantoins, which were present in the same extract as diketopiperazine, were suggested to be formed by intramolecular dehydration of $\mathrm{N}$-carbamyl amino acids in the parent body of Murchison [49]. However, analysis by Shimoyama and Ogasawara [48] did not support formation of hydantoin through $\mathrm{N}$-carboxyanhydrides of glycine. Indeed, while the concentrations of hydantoin and 5-methylhydantoin were roughly equal in the Yamato-791198 meteorite (Table 3), only Gly-Gly was detected (no glycylalanine, alanylglycine, and alanylalanine were detected) [48]. Alternatively, vacuum UV photo-irradiation of interstellar/circumstellar ice analogues containing $\mathrm{H}_{2} \mathrm{O}, \mathrm{CH}_{3} \mathrm{OH}$ and $\mathrm{NH}_{3}$ has been shown to form small quantities of hydantoin [54].

\subsection{Purines, Pyrimidines, Triazines, Pyridines, and Quinolines}

Several researchers have detected purines, pyrimidines, triazines, pyridines, and quinolines in carbonaceous chondrites (Figure 1, structures D1 to H3) [47,55-66]. Throughout the years, there has been controversy regarding the detection of these compounds, as different research groups found different purines, pyrimidines, and triazines, in some cases for the same meteorite. Purines (adenine and guanine) and triazines (melamine and ammeline) (Figure 1, structures D4, D5, F1, F2, respectively) were detected in the Orgueil meteorite (CI1) by Hayatsu and co-authors [55,56]. Adenine, guanine, melamine, and cyanuric acid (Figure 1, structure F3) were also detected in Orgueil by the same research 
group when using drastic extraction conditions (hot temperature, 3-6 $\mathrm{M} \mathrm{HCl}$ or $\mathrm{CF}_{3} \mathrm{COOH}_{\text {) [57]. }}$ On the other hand, Folsome and co-authors found 4-hydroxypyrimidine (Figure 1, structure E2) and heterogenous classes of speculative pyrimidines in Murchison (CM2), Murray (CM2), and Orgueil, which did not agree with the results of Hayatsu and co-authors [58-60]. The explanation for this discrepancy was found a few years later. Xanthine, and tentatively guanine and hypoxanthine (Figure 1 , structures D7, D5, D6, respectively) were detected in formic acid extracts of the Murchison meteorite by dual-column, ion-exclusion chromatography and ultraviolet spectroscopy [61]. Hydroxypyrimidines were detected only after the silylation of a water extract, suggesting that the compounds previously detected were terrestrial contaminants from the silylation reagent [61]. Uracil (Figure 1, structure E1) was detected for the first time in water and formic acid extracts of Murchison, Murray, and Orgueil using fractionation techniques and ion exclusion chromatography with UV spectroscopy [62]. Orgueil contained $27 \mathrm{ppb}$, while Murchison contained 33 ppb of uracil (Table 4). Adenine, guanine, hypoxanthine, and xanthine were also detected in formic acid extracts of these three meteorites [63]. Triazines were not detected and, similarly to hydroxypyrimidines, were suggested to be terrestrial contamination resulting from the experimental procedures used previously $[55,56]$. The efficiency of the extraction procedure for purines, pyrimidines and triazines was determined by extracting a sample of the Allende meteorite (CV3), which was spiked with known amounts of standard compounds [63]. Recoveries of these compounds for the water extraction after desalting ranged from $41 \%$ to $81 \%$, while for formic acid, it had an average recovery of 71\% [63]. A conclusion about the origin of purines and pyrimidines detected in meteorites was obtained in 2008 when compound-specific carbon isotope measurements of these compounds were performed by using gas chromatography-combustion-isotope ratio mass spectrometry (GC-C-IRMS) [65]. Carbon isotope ratios of uracil and xanthine in Murchison $\left(\delta^{13} \mathrm{C}=+44.5 \%\right.$ and $+37.7 \%$, respectively), and of uracil and thymine from a soil collected in the proximity of the meteorite fall site $\left(\delta^{13} \mathrm{C}=-10.6 \%\right.$ and $-15.9 \%$, respectively) showed that uracil and xanthine detected in the Murchison meteorite were enriched in ${ }^{13} \mathrm{C}$ and therefore were indigenous to this meteorite (Table 5) [65]. Purines and pyrimidines were detected in several other meteorites. Guanine, and possible xanthine and hypoxanthine, were detected in formic acid extracts of Y-74662 (CM2) and Y-791198 (CM2) [64]. Purine, purine-2,6-diamine, purine-6,8-diamine (Figure 1, structures D1 to D3), adenine, guanine, hypoxanthine, and xanthine were detected in some of the following meteorites: Orgueil (CI1), Meteorite Hills (MET) 01070 (CM1), Scott Glacier (SCO) 06043, (CM1) Allan Hills (ALH) 83100 (CM1/2), Lewis Cliff (LEW) 90500 (CM2), Lonewolf Nunataks (LON) 94102 (CM2), Murchison (CM2), Grosvenor Mountains (GRO) 95577 (CR1), Elephant Moraine (EET) 92042 (CR2), Graves Nunataks (GRA) 95229 (CR2), and Queen Alexandra Range (QUE) 99177 (CR2) [66]. The total purine abundances were up to 12 times higher in CM2 carbonaceous chondrites than in the other analysed meteorites (Table 4, [66]). Within CM chondrites, the abundances and diversity of purines decreased with increasing aqueous alteration [66]. Pyridines (2,4,6-trimethylpyridine) (Figure 1, structure G1) and quinolines (quinoline, isoquinoline, 2-methylquinoline and 4-methylquinoline) (Figure 1, structures H1 to H5) were also detected in Murchison [47]. 
Table 4. The abundances (ppb) of purines [66] and a pyrimidine [62] in formic acid extracts of carbonaceous meteorites. Numbers in parentheses represent concentrations for tentative structural assignments (i.e., they were usually due to low S/N coupled with a complex multiple reaction monitoring (MRM) chromatogram, not allowing for unambiguous assignment). The + sign indicates the positive identification for the compound (but no quantitation).

\begin{tabular}{|c|c|c|c|c|c|c|c|c|c|c|c|}
\hline & Orgueil & SCO 06043 & MET 01070 & GRO 95577 & ALH 83100 & Murchison & LEW 90500 & LON 94102 & GRA 95229 & EET 92042 & QUE 99177 \\
\hline Guanine & 20 & (2) & 29 & $<2^{+}$ & 21 & 56 & 167 & 244 & 4 & $<2^{+}$ & $<2^{+}$ \\
\hline Hypoxanthine & (5) & (4) & $<3^{+}$ & $<3^{+}$ & 4 & 26 & 23 & 94 & (4) & $<3$ & $<3^{+}$ \\
\hline Xanthine & $<10^{+}$ & $<10^{+}$ & $<10^{+}$ & $<10^{+}$ & (4) & 60 & 22 & 77 & $<10^{+}$ & $<10^{+}$ & $<10^{+}$ \\
\hline Adenine & 7 & 4 & 5 & $<0.5$ & 1 & 5 & 10 & 30 & 21 & 5 & 11 \\
\hline Purine & 5 & $<1^{+}$ & $<1^{+}$ & $<1^{+}$ & $<0.1^{\dagger}$ & 3 & 1 & 6 & 9 & (4) & 7 \\
\hline 2,6-Diamonopurine & $<2^{+}$ & $<2^{+}$ & $<2^{+}$ & $<2$ & $<0.2^{\dagger}$ & + & $<0.2^{\dagger}$ & 5 & $<2^{+}$ & $<2^{\dagger}$ & $<2^{+}$ \\
\hline Uracil & 27 & n.d. & n.d. & n.d. & n.d & 33 & n.d. & n.d. & n.d. & n.d. & n.d. \\
\hline
\end{tabular}

Table 5. Compound-specific stable isotope composition $\left(\delta^{13} \mathrm{C}\right.$ in $\%$ ) of uracil and xanthine in Murchison [65].

\begin{tabular}{cc}
\hline & Murchison \\
\hline Uracil & $+44.5 \pm 2.3$ \\
Xanthine & $+37.7 \pm 1.6$ \\
\hline
\end{tabular}


Synthesis of Purines, Pyrimidines, Pyridines, and Quinolines

Only upper limits of pyrimidines, pyridine, quinoline, and isoquinolines were detected in the gas phase of astrophysical environments [67-70], which may be explained by their low stability against UV radiation in these environments [71,72]. Laboratory work has demonstrated that uracil, cytosine, and thymine may be formed by UV photoirradiation of astrophysical ice analogues containing pyrimidine [73-76]. UV photoirradiation of purine mixed with combinations of $\mathrm{H}_{2} \mathrm{O}$ and $\mathrm{NH}_{3}$ ices resulted in the formation of adenine, guanine, and other purine derivatives [77]. The formation of adenine, guanine, and analogues in a UV-irradiated mixed $\mathrm{H}_{2} \mathrm{O}: \mathrm{NH}_{3}$ ice (10:1) containing purine was confirmed by using $a b$ initio and density functional theory computations [78]. These investigations suggested a multistep reaction mechanism involving water, ammonia, a purine cation, and hydroxyl and amino radicals. They predicted that mono-substituted products (preferentially adenine and 2-hydroxypurine) were more energetically favourable, followed by bi-substituted product (preferentially isoguanine and xanthine) [78]. Experimental results were in agreement with ab initio, with adenine and hypoxanthine as the most abundant products, followed by the bi-substituted photoproducts [77]. Purines and pyrimidines may also be formed by polymerization of ammonium cyanide solutions at temperatures ranging from $-78{ }^{\circ} \mathrm{C}$ to $+80^{\circ} \mathrm{C}$, which could have happened in the parent body of carbonaceous chondrites [79-89]. Thermochemical computational simulations show that Fischer-Tropsch type (FTT) synthesis is likely the dominant source of nucleobases within a meteorite parent body (planetesimal) model, followed by non-catalytic synthesis (under certain chemical conditions) [90]. Pyridine, quinoline, and isoquinoline can be formed from the UV irradiation of benzene and naphthalene in $\mathrm{H}_{2} \mathrm{O}$ and $\mathrm{H}_{2} \mathrm{O}: \mathrm{NH}_{3}$ ices at low temperature [91]. This study also showed that these compounds may be formed in icy grains without requiring that they be formed in or condense from the gas phase, therefore avoiding photodegradation [91]. Other suggested formation mechanisms of pyridines include FTT reactions, e.g., the synthesis of alkyl pyridines by catalytic reactions of aldehydes and ammonia [47].

\subsection{Carboxylactams, Lactams, and Lactims}

Several carboxylactams were detected in the Murchison meteorites, including 5-oxoproline, 2-methyl-5-oxoproline, 6-oxo-2-piperidinecarboxylic acid, and 7-oxo-2-azepanecarboxylic acid (Figure 1, structures I1 to I4) [49]. Although no abundances were determined for this class of compounds, results suggest that the alkyl-substituted five-and six-membered ring carboxy lactams are the most abundant. Lactams are also present in the Murchison meteorite, including the five-membered ring compound 2-pyrrolidone to at least the nine membered ring compound 2-azonanone (Figure 1, structures $\mathbf{J} \mathbf{1}$ to J6). Both lactams and carboxylactams present in Murchison include most of their structural isomers based on mass spectra and retention time comparison to those of silylated standard compounds or mass spectra with the expected fragment ions [49]. For the carboxylactams, the seven-carbon isomers (i.e., alkyl-substituted five-and six-membered ring carboxy lactams) are the most abundant members of the series, and a nine-carbon homologue is the highest member of the series. The lactams start with the five-membered ring compound and extends to at least the nine membered ring compound (8-octanelactam) [49]. Finally, 2,5-pyrrolidinedione and 2,6-piperidinedione (two lactims) were also positively identified in the Murchison meteorite (Figure 1, structures K1 and K2).

Synthesis of Carboxylactams, Lactams, and Lactims

The mechanisms for the synthesis of carboxylactams, lactams and lactims in carbonaceous meteorites have been proposed [49]. Carboxylactams were suggested to be formed by dehydration of $\mathrm{N}$-carbamyl amino acids (formed by the reaction of cyanates with amino acids), with subsequent decarboxylation leading to lactams. Alternatively, carboxylactams would be formed via dehydration of the corresponding amino acid. The reaction of hydantoins with cyanates would form an acid amide derivative, which would subsequently synthesize a lactim via dehydration [49]. 


\subsection{Amino acid Proline}

The amino acid proline (Figure 1, structure L1) was detected in Murchison and Murray [92,93]. Concentrations of proline ranged from 622 to $1550 \mathrm{ppb}$ in the Murchison meteorite, while it was $400 \mathrm{ppb}$ in Murray [93-96]. The indigenous nature of proline in Murchison was indicated by its stable nitrogen isotope composition ( $\delta^{15} \mathrm{~N}$ value of $+50 \%$ for D,L-proline) [97].

Synthesis of the Amino Acid Proline

Amino acids may be formed by UV photolysis of interstellar ice analogs. In fact, proline was found in the residues of interstellar ice analogs processed with UV radiation [98,99]. A radical-radical mechanism of formation of amino acids in interstellar ice analogs was proposed [100]. It was later shown that a modified radical-radical mechanism could happen, but general amino acid formation occurs via multiple pathways [101]. A more recent study using chemical retrosynthesis shows that proline in interstellar ices may be formed from the amine precursor butylamine [102].

\section{Astrophysical and Astrobiological Implications of Meteoritic $\mathrm{N}$-Heterocycles}

Several $N$-heterocycles have been detected in carbonaceous chondrites, and their synthesis may have an interstellar heritage via low temperature reactions, followed by accretion to the meteorite parent body. Furthermore, aqueous alteration in the meteorite parent may have also played a role on its own on the synthesis of $N$-heterocycles or after interstellar medium synthesis and accretion [17,41]. Although compound-specific carbon, hydrogen, or nitrogen isotopic compositions have been performed for $\mathrm{N}$-heterocycles, the available data are extremely limited and were obtained for only a handful of individual compounds $[44,45,65,96]$ (Tables 1 and 5). The lack of an extensive study on the simultaneous analysis of at least two sets of data of the compound-specific carbon, hydrogen, or nitrogen isotopic compositions for all the detected classes of meteoritic $N$-heterocycles forfeits a complete understanding of the mechanisms of formation of these compounds. This research is certainly worth exploring in the future to fully master their formation mechanisms.

The prebiotic contribution of meteoritic $N$-heterocycles must be viewed first in light of their solubility on the oceans of the primitive Earth, i.e., how easily they are extracted from carbonaceous chondrites and could be used in chemical reactions on our early planet, followed by their potential use by primitive living organisms. Some $N$-heterocycles (e.g., pyridine carboxylic acids, hydantoins, purines, pyrimidine, etc.) are soluble in water, which means that they could potentially participate in primitive biological systems. However, the abundances of individual $\mathrm{N}$-heterocycles in carbonaceous chondrites are low, in the order of a few ppb (Tables 2-4), which indicates that carbonaceous meteorites were probably not the only source of $N$-heterocyles on the early Earth. In addition, it has not yet been found how to synthesise ribonucleotides from nucleobases (and ribose) under prebiotic conditions, as the addition of nucleobases to ribose is either inefficient or does not occur [103,104]. Nevertheless, none of these preclude the use of meteoritic $N$-heterocycles on primitive biological systems. Indeed, in present-day biology, the amino acid proline is used in the biosynthesis of proteins, while $\mathrm{N}$-heterocycles are components of the co-factors of enzymes and of genetic material (RNA and DNA) [20].

\section{Conclusions}

This manuscript reviews the nitrogen heterocycle content of meteorites, including the abundances and the compound-specific carbon and hydrogen isotopic compositions of individual compounds in the soluble organic fraction. Likely indigenous meteoritic nitrogen heterocycles included pyridine carboxylic acids, piperazinedione, hydantoins, purines, pyrimidines, pyridines, quinolines, carboxylactams, lactams, lactims, and proline. Formation mechanisms included reactions in the interstellar medium, followed by accretion and processing on the meteorite parent body. While likely 
not the only source of $\mathrm{N}$-heterocycles used by primitive living organisms, carbonaceous meteorites contributed to the feedstock of organic molecules freely available on the early Earth.

Funding: This research received no external funding.

Acknowledgments: The author would like to kindly acknowledge the constructive comments of three anonymous reviewers that greatly improved the quality of this manuscript.

Conflicts of Interest: The author declares no conflict of interest.

\section{References}

1. McSween, H.Y., Jr.; Huss, G.R. Cosmochemistry; McSween, H.Y., Jr., Huss, G.R., Eds.; Cambridge University Press: Cambridge, UK, 2015.

2. Bischoff, A.; Vogel, N.; Roszjar, J. The Rumuruti chondrite group. Chem. Erde Geochem. 2011, 71, 101-133. [CrossRef]

3. Krot, A.N.; Keil, K.; Scott, E.R.D.; Goodrich, C.A.; Weisberg, M.K. Classification of meteorites and their genetic relationships. In Meteorites and Cosmochemical Processes; Davis, A.M., Ed.; Volume 1 of Treatise on Geochemistry; Elsevier: New York, NY, USA, 2014; pp. 1-63.

4. Lodders, K. Solar system abundances and condensation temperatures of the elements. Astrophys. J. 2003, 591, 1220-1247. [CrossRef]

5. Choe, W.H.; Huber, H.; Rubin, A.E.; Kallemeyn, G.W.; Wasson, J.T. Compositions and taxonomy of 15 unusual carbonaceous chondrites. Meteorit. Planet. Sci. 2010, 45, 531-554. [CrossRef]

6. McSween, H.Y. Alteration in CM carbonaceous chondrites inferred from modal and chemical variations in matrix. Geochim. Cosmochim. Acta 1979, 43, 1761-1770. [CrossRef]

7. Browning, L.B.; McSween, H.Y.; Zolensky, M.E. Correlated alteration effects in CM carbonaceous chondrites. Geochim. Cosmochim. Acta 1996, 60, 2621-2633. [CrossRef]

8. Palmer, E.E.; Lauretta, D.S. Aqueous alteration of kamacite in CM chondrites. Meteorit. Planet. Sci. 2011, 46, 1587-1607. [CrossRef]

9. Vinogradoff, V.; Le Guillou, C.; Bernard, S.; Binet, L.; Cartigny, P.; Brearley, A.J.; Remusat, L. Paris vs. Murchison: Impact of hydrothermal alteration on organic matter in CM chondrites. Geochim. Cosmochim. Acta 2017, 212, 234-252. [CrossRef]

10. Alexander, C.M.O.D.; Nittler, L.R.; Davidson, J.; Ciesla, F.J. Measuring the level of interstellar inheritance in the solar protoplanetary disk. Meteorit. Planet. Sci. 2017, 52, 1797-1821. [CrossRef]

11. Smith, J.W.; Kaplan, I.R. Endogenous carbon in carbonaceous meteorites. Science 1970, 167, 1367-1370. [CrossRef] [PubMed]

12. Anders, E.; Zinner, E. Interstellar grains in primitive meteorites-Diamond, silicon carbide, and graphite. Meteoritics 1993, 28, 490-514. [CrossRef]

13. Benedix, G.K.; Leshin, L.A.; Farquhar, J.; Jackson, T.; Thiemens, M.H. Carbonates in CM2 chondrites: Constraints on alteration conditions from oxygen isotopic compositions and petrographic observations. Geochim. Cosmochim. Acta 2003, 67, 1577-1588. [CrossRef]

14. Gardinier, A.; Derenne, S.; Robert, F.; Behar, F.; Largeau, C.; Maquet, J. Solid state CP/MAS ${ }^{13}$ C NMR of the insoluble organic matter of the Orgueil and Murchison meteorites: Quantitative study. Earth Planet. Sci. Lett. 2000, 184, 9-21. [CrossRef]

15. Cody, G.D.; Alexander, C.M.O.; Tera, F. Solid-state $\left({ }^{1} \mathrm{H}\right.$ and $\left.{ }^{13} \mathrm{C}\right)$ nuclear magnetic resonance spectroscopy of insoluble organic residue in the Murchison meteorite: A self-consistent quantitative analysis. Geochim. Cosmochim. Acta 2002, 66, 1851-1865. [CrossRef]

16. Cody, G.D.; Alexander, C.M.O. NMR studies of chemical structural variation of insoluble organic matter from different carbonaceous chondrites groups. Geochim. Cosmochim. Acta 2005, 69, 1085-1097. [CrossRef]

17. Cronin, J.R.; Chang, S. Organic matter in meteorites: Molecular and isotopic analyses of the Murchison meteorites. In The Chemistry of Life's Origin; Greenberg, J.M., Mendoza-Gomez, C.X., Pirronello, V., Eds.; Kluwer Academic Publishers: Dordrecht, The Netherlands, 1993; pp. 209-258.

18. Martins, Z.; Sephton, M.A. Extraterrestrial amino acids. In Amino Acids, Peptides and Proteins in Organic Chemistry; Hughes, A.B., Ed.; Wiley: Hoboken, NJ, USA, 2009; pp. 3-42.

19. Martins, Z. Organic chemistry of carbonaceous meteorites. Elements 2011, 7, 35-40. [CrossRef] 
20. Joule, J.A.; Mills, K. Heterocyclic Chemistry; John Wiley \& Sons: Hoboken, NJ, USA, 2013.

21. Schidlowski, M. A 3800-million-year isotopic record of life from carbon in sedimentary rocks. Nature 1988, 333, 313-318. [CrossRef]

22. Rosing, M.T. ${ }^{13}$ C-Depleted carbon microparticles in $>3700$-Ma sea-floor sedimentary rocks from west Greenland. Science 1999, 283, 674-676. [CrossRef] [PubMed]

23. Furnes, H.; Banerjee, N.R.; Muehlenbachs, K.; Staudigel, H.; de Wit, M. Early Life Recorded in Archean Pillow Lavas. Science 2004, 304, 578-581. [CrossRef] [PubMed]

24. Rosing, M.T.; Frei, R. U-rich Archaean sea-floor sediments from Greenland-Indications of $>3700 \mathrm{Ma}$ oxygenic photosynthesis. Earth Planet. Sci. Lett. 2004, 217, 237-244. [CrossRef]

25. Westall, F.; de Vries, S.T.; Nijman, W.; Rouchon, V.; Orberger, B.; Pearson, V.; Watson, J.; Verdosvsky, A.; Wright, I.; Rouzaud, J.N.; et al. The 3.466 Ga "Kitty's Gap Chert," an Early Archaean microbial ecosystem. In Processes on the Early Earth; Reimold, W.U., Gibson, R.L., Eds.; Geological Society America: Boulder, CO, USA, 2006; pp. 105-131.

26. Westall, F.; Cavalazzi, B.; Lemelle, L.; Marrocchi, Y.; Rouzaud, J.-N.; Simionovici, A.; Salomé, M.; Mostefaoui, S.; Andreazza, C.; Foucher, F.; et al. Implications of in situ calcification for photosynthesis in a 3.3-Ga-old microbial biofilm from the Barberton greenstone belt, South Africa. Earth Planet. Sci. Lett. 2011, 310, 468-479. [CrossRef]

27. Westall, F.; Foucher, F.; Cavalazzi, B.; de Vries, S.T.; Nijman, W.; Pearson, V.; Watson, J.; Verchovsky, A.; Wright, I.; Rouzaud, J.-N.; et al. Early life on Earth and Mars: A case study from 3.5 Ga-old rocks from the Pilbara, Australia. Planet. Space Sci. 2011, 59, 1093-1106. [CrossRef]

28. Sugitani, K.; Grey, K.; Nagaoka, T.; Mimura, K.; Walter, M.R. Taxonomy and biogenicity of Archaean spheroidal microfossils (ca. 3.0 Ga) from the Mount Goldsworthy-Mount Grant area in the northeastern Pilbara Craton, Western Australia. Precambrian Res. 2009, 173, 50-59. [CrossRef]

29. Javaux, E.J.; Marshall, C.P.; Bekker, A. Organic-walled microfossils in 3.2-billion-year-old shallow-marine siliciclastic deposits. Nature 2010, 463, 934-938. [CrossRef] [PubMed]

30. Wacey, D.; McLoughlin, N.; Whitehouse, M.J.; Kilburn, M.R. Two coexisting sulfur metabolisms in a ca. 3400 Ma sandstone. Geology 2010, 38, 1115-1118. [CrossRef]

31. Chyba, C.; Sagan, C. Endogenous production, exogenous delivery and impact-shock synthesis of organic molecules: An inventory for the origins of life. Nature 1992, 355, 125-132. [CrossRef] [PubMed]

32. Schopf, J.W. Microfossils of the Early Archean: New evidence of the antiquity of life. Science 1993, 260, 640-646. [CrossRef] [PubMed]

33. Yuen, G.; Blair, N.; Des Marais, D.J.; Chang, S. Carbon isotope composition of low molecular weight hydrocarbons and monocarboxylic acids from Murchison meteorite. Nature 1984, 307, 252-254. [CrossRef] [PubMed]

34. Krishnamurthy, R.V.; Epstein, S.; Cronin, J.R.; Pizzarello, S.; Yuen, G.U. Isotopic and molecular analyses of hydrocarbons and monocarboxylic acids of the Murchison meteorite. Geochim. Cosmochim. Acta 1992, 56, 4045-4058. [CrossRef]

35. Cronin, J.R.; Pizzarello, S.; Epstein, S.; Krishnamurthy, R.V. Molecular and isotopic analyses of the hydroxy acids, dicarboxylic acids, and hydroxydicarboxylic acids of the Murchison meteorite. Geochim. Cosmochim. Acta 1993, 57, 4745-4752. [CrossRef]

36. Tielens, A.G.G.M. Surface chemistry of deuterated molecules. Astron. Astrophys. 1983, 119, 177-184.

37. Yang, J.; Epstein, S. Interstellar organic matter in meteorites. Geochim. Cosmochim. Acta 1983, 47, $2199-2216$. [CrossRef]

38. Terzieva, R.; Herbst, E. The possibility of nitrogen isotopic fractionation in interstellar clouds. Mon. Not. R. Astron. Soc. 2000, 317, 563-568. [CrossRef]

39. Sandford, S.A.; Bernstein, M.P.; Dworkin, J.P. Assessment of the interstellar processes leading to deuterium enrichment in meteoritic organics. Meteorit. Planet. Sci. 2001, 36, 1117-1133. [CrossRef]

40. Robert, F. The D/H ratio in chondrites. Space Sci. Rev. 2003, 106, 87-101. [CrossRef]

41. Aléon, J.; Robert, F. Interstellar chemistry recorded by nitrogen isotopes in Solar System organic matter. Icarus 2004, 167, 424-430. [CrossRef]

42. Grimm, R.E.; McSween, H.Y. Water and the thermal evolution of carbonaceous chondrite parent bodies. Icarus 1989, 82, 244-280. [CrossRef] 
43. Pizzarello, S.; Huang, Y.; Becker, L.; Poreda, R.J.; Nieman, R.A.; Cooper, G.; Williams, M. The organic content of the Tagish Lake meteorite. Science 2001, 293, 2236-2239. [CrossRef] [PubMed]

44. Pizzarello, S.; Huang, Y.; Fuller, M. The carbon isotopic distribution of Murchison amino acids. Geochim. Cosmochim. Acta 2004, 68, 4963-4969. [CrossRef]

45. Pizzarello, S.; Huang, Y. The deuterium enrichment of individual amino acids in carbonaceous meteorites: A case for the presolar distribution of biomolecule precursors. Geochim. Cosmochim. Acta 2005, 69, 599-605. [CrossRef]

46. Smith, K.E.; Callahan, M.P.; Gerakines, P.A.; Dworkin, J.P.; House, C.H. Investigation of pyridine carboxylic acids in CM2 carbonaceous chondrites: Potential precursor molecules for ancient coenzymes. Geochim. Cosmochim. Acta 2014, 136, 1-12. [CrossRef]

47. Stoks, P.G.; Schwartz, A.W. Basic nitrogen-heterocyclic compounds in the Murchison meteorite. Geochim. Cosmochim. Acta 1982, 46, 309-315. [CrossRef]

48. Shimoyama, A.; Ogasawara, R. Dipeptides and diketopiperazines in the Yamato-791198 and Murchison carbonaceous chondrites. Orig. Life Evol. Biosph. 2002, 32, 165-179. [CrossRef] [PubMed]

49. Cooper, G.W.; Cronin, J.R. Linear and cyclic aliphatic carboxamides of the Murchison meteorite: Hydrolyzable derivatives of amino acids and other carboxylic acids. Geochim. Cosmochim. Acta 1995, 59, 1003-1015. [CrossRef]

50. Bujdak, J.; Rode, B.M. Silica, alumina, and clay-catalyzed alanine peptide bond formation. J. Mol. Evol. 1997, 45, 457-466. [CrossRef]

51. Bujdak, J.; Rode, B.M. Silica, alumina and clay catalyzed peptide bond formation: Enhanced efficiency of alumina catalyst. Orig. Life Evol. Biosph. 1999, 29, 451-461. [CrossRef] [PubMed]

52. Lahav, N.; White, D.; Chang, S. Peptide formation in the prebiotic era: Thermal condensation of glycine in fluctuating clay environments. Science 1978, 201, 67-69. [CrossRef] [PubMed]

53. Lawless, J.G.; Levi, N. The role of metal ions in chemical evolution: Polymerization of alanine and glycine in a cation-exchanged clay environment. J. Mol. Evol. 1979, 13, 281-286. [CrossRef] [PubMed]

54. de Marcellus, P.; Bertrand, M.; Nuevo, M.; Westall, F.; Le Sergeant d'Hendecourt, L. Prebiotic significance of extraterrestrial ice photochemistry: Detection of hydantoin in organic residues. Astrobiology 2011, 11, 847-854. [CrossRef] [PubMed]

55. Hayatsu, R. Orgueil meteorite: Organic nitrogen contents. Science 1964, 146, 1291-1293. [CrossRef] [PubMed]

56. Hayatsu, R.; Studier, M.H.; Oda, A.; Fuse, K.; Anders, E. Origin of organic matter in early solar system-II. Nitrogen compounds. Geochim. Cosmochim. Acta 1968, 32, 175-190. [CrossRef]

57. Hayatsu, R.; Studier, M.H.; Moore, L.P.; Anders, E. Purines and triazines in the Murchison meteorite. Geochim. Cosmochim. Acta 1975, 39, 471-488. [CrossRef]

58. Folsome, C.E.; Lawless, J.; Romiez, M.; Ponnamperuma, C. Heterocyclic compounds indigenous to the Murchison meteorite. Nature 1971, 232, 108-109. [CrossRef] [PubMed]

59. Folsome, C.E.; Lawless, J.; Romiez, M.; Ponnamperuma, C. Heterocyclic compounds recovered from carbonaceous chondrite. Geochim. Cosmochim. Acta 1973, 37, 455-465. [CrossRef]

60. Lawless, J.G.; Folsome, C.E.; Kvenvolden, K.A. Organic matter in meteorites. Sci. Am. 1972, $226,38-46$. [CrossRef]

61. Van der Velden, W.; Schwartz, A.W. Search for purines and pyrimidines in Murchison meteorite. Geochim. Cosmochim. Acta 1977, 41, 961-968. [CrossRef]

62. Stoks, P.G.; Schwartz, A.W. Uracil in carbonaceous meteorites. Nature 1979, 282, 709-710. [CrossRef]

63. Stoks, P.G.; Schwartz, A.W. Nitrogen-heterocyclic compounds in meteorites: Significance and mechanisms of formation. Geochim. Cosmochim. Acta 1981, 45, 563-569. [CrossRef]

64. Shimoyama, A.; Hagishita, S.; Harada, K. Search for nucleic acid bases in carbonaceous chondrites from Antarctica. Geochem. J. 1990, 24, 343-348. [CrossRef]

65. Martins, Z.; Botta, O.; Fogel, M.L.; Sephton, M.A.; Glavin, D.P.; Watson, J.S.; Dworkin, J.P.; Schwartz, A.W.; Ehrenfreund, P. Extraterrestrial nucleobases in the Murchison meteorite. Earth Planet. Sci. Lett. 2008, 270, 130-136. [CrossRef]

66. Callahan, M.P.; Smith, K.E.; Cleaves, H.J.; Ruzicka, J.; Stern, J.C.; Glavin, D.P.; House, C.H.; Dworkin, J.P. Carbonaceous meteorites contain a wide range of extraterrestrial nucleobases. Proc. Natl. Acad. Sci. USA 2011, 108, 13995-13998. [CrossRef] [PubMed] 
67. Simon, M.N.; Simon, M. Search for interstellar acrylonitrile, pyrimidine, and pyridine. Astrophys. J. 1973, 184, 757-762. [CrossRef]

68. Kuan, Y.-J.; Charnley, S.B.; Huang, H.-C.; Kisiel, Z.; Ehrenfreund, P.; Tseng, W.-L.; Yan, C.-H. Searches for interstellar molecules of potential prebiotic importance. Adv. Space Res. 2004, 33, 31-39. [CrossRef]

69. Charnley, S.B.; Kuan, Y.-J.; Huang, H.-C.; Botta, O.; Butner, H.M.; Cox, N.; Despois, D.; Ehrenfreund, P.; Kisiel, Z.; Lee, Y.-Y.; et al. Astronomical searches for nitrogen heterocycles. Adv. Space Res. 2005, 36, 137-145. [CrossRef]

70. Brünken, S.; McCarthy, M.C.; Thaddeus, P.; Godfrey, P.D.; Brown, R.D. Improved line frequencies for the nucleic acid base uracil for a radioastronomical search. Astron. Astrophys. 2006, 459, 317-320. [CrossRef]

71. Peeters, Z.; Botta, O.; Charnley, S.B.; Ruiterkamp, R.; Ehrenfreund, P. The astrobiology of nucleobases. Astrophys. J. 2003, 593, L129-L132. [CrossRef]

72. Peeters, Z.; Botta, O.; Charnley, S.B.; Kisiel, Z.; Kuan, Y.-J.; Ehrenfreund, P. Formation and photostability of N-heterocycles in space. I. The effect of nitrogen on the photostability of small aromatic molecules. Astron. Astrophys. 2005, 433, 583-590. [CrossRef]

73. Nuevo, M.; Milam, S.N.; Sandford, S.A.; Elsila, J.E.; Dworkin, J.P. Formation of uracil from the ultraviolet photo-irradiation of pyrimidine in pure $\mathrm{H}_{2} \mathrm{O}$ ices. Astrobiology 2009, 9, 683-695. [CrossRef] [PubMed]

74. Nuevo, M.; Materese, C.K.; Sandford, S.A. The photochemistry of pyrimidine in realistic astrophysical ices and the production of nucleobases. Astrophys. J. 2014, 793, 125. [CrossRef]

75. Nuevo, M.; Milam, S.N.; Sandford, S.A. Nucleobases and prebiotic molecules in organic residues produced from the ultraviolet photo-irradiation of pyrimidine in $\mathrm{NH}_{3}$ and $\mathrm{H}_{2} \mathrm{O}+\mathrm{NH}_{3}$ ices. Astrobiology 2012, 12, 295-314. [CrossRef] [PubMed]

76. Materese, C.K.; Nuevo, M.; Bera, P.P.; Lee, T.J.; Sandford, S.A. Thymine and other prebiotic molecules produced from the ultraviolet photo-irradiation of pyrimidine in simple astrophysical ice analogs. Astrobiology 2013, 13, 948-962. [CrossRef] [PubMed]

77. Materese, C.K.; Nuevo, M.; Sandford, S.A. The formation of nucleobases from the Ultraviolet photoirradiation of purine in simple astrophysical ice analogues. Astrobiology 2017, 17, 761-770. [CrossRef] [PubMed]

78. Bera, P.P.; Stein, T.; Head-Gordon, M.; Lee, T.J. Mechanisms of the formation of adenine, guanine, and their analogues in UV-irradiated mixed $\mathrm{NH}_{3}: \mathrm{H}_{2} \mathrm{O}$ molecular ices containing purine. Astrobiology 2017, 17, 771-785. [CrossRef] [PubMed]

79. Oró, J. Synthesis of adenine from ammonium cyanide. Biochem. Biophys. Res. Commun. 1960, 2, 407-412. [CrossRef]

80. Oró, J. Mechanism of synthesis of adenine from hydrogen cyanide under possible primitive Earth conditions. Nature 1961, 191, 1193-1194. [CrossRef] [PubMed]

81. Oró, J.; Kimball, A.P. Synthesis of purines under possible primitive Earth conditions I. Adenine from hydrogen cyanide. Arch. Biochem. Biophys. 1961, 94, 217-227. [CrossRef]

82. Sanchez, R.A.; Ferris, J.P.; Orgel, L.E. Studies in prebiotic synthesis. II. Synthesis of purine precursors and amino acids from aqueous hydrogen cyanide. J. Mol. Biol. 1967, 30, 223-253. [PubMed]

83. Ferris, J.P.; Joshi, P.C.; Edelson, E.H.; Lawless, J.G. HCN: A plausible source of purines, pyrimidines and amino acids on the primitive Earth. J. Mol. Evol. 1978, 11, 293-311. [CrossRef] [PubMed]

84. Voet, A.B.; Schwartz, A.W. Uracil synthesis via HCN oligomerization. Orig. Life 1982, 12, 45-49. [CrossRef] [PubMed]

85. Schwartz, A.W.; Bakker, C.G. Was adenine the first purine? Science 1989, 245, 1102-1104. [CrossRef] [PubMed]

86. Pesce-Rodriguez, R.A.; Liebman, S.A.; Matthews, C.N. Characterization of hydrogen cyanide polymers and the Murchison meteorite: Implications for prebiotic and extraterrestrial chemistry. Orig. Life Evol. Biosph. 1994, 24, 123-124.

87. Minard, R.D.; Hatcher, P.G.; Gourley, R.C.; Matthews, C.N. Structural investigations of hydrogen cyanide polymers: New insights using TMAH thermochemolysis/GC-MS. Orig. Life Evol. Biosph. 1998, 28, 461-473. [CrossRef] [PubMed]

88. Levy, M.; Miller, S.L.; Oró, J. Production of guanine from $\mathrm{NH}_{4} \mathrm{CN}$ polymerizations. J. Mol. Evol. 1999, 49, 165-168. [CrossRef] [PubMed]

89. Miyakawa, S.; Cleaves, H.J.; Miller, S.L. The cold origin of life: B. Implications based on pyrimidines and purines produced from frozen ammonium cyanide solutions. Orig. Life Evol. Biosph. 2002, 32, 209-218. [CrossRef] [PubMed] 
90. Pearce, B.K.D.; Pudritz, R.E. Meteorites and the RNA World: A thermodynamic model of nucleobase synthesis within planetesimals. Astrobiology 2016, 16, 853-872. [CrossRef] [PubMed]

91. Materese, C.K.; Nuevo, M.; Sandford, S.A. N- and O-heterocycles produced from the irradiation of benzene and naphthalene in $\mathrm{H}_{2} \mathrm{O} / \mathrm{NH}_{3}$-containing ices. Astrophys. J. 2015, 800, 116. [CrossRef]

92. Kvenvolden, K.; Lawless, J.; Pering, K.; Peterson, E.; Flores, J.; Ponnamperuma, C. Evidence for extraterrestrial amino acids and hydrocarbons in the Murchison meteorite. Nature 1970, 228, 923-926. [CrossRef] [PubMed]

93. Cronin, J.R.; Moore, C.B. Amino acid analyses of the Murchison, Murray, and Allende carbonaceous chondrites. Science 1971, 172, 1327-1329. [CrossRef] [PubMed]

94. Kvenvolden, K.A.; Lawless, J.G.; Ponnamperuma, C. Nonprotein amino acids in the Murchison meteorite. Proc. Natl. Acad. Sci. USA 1971, 68, 486-490. [CrossRef] [PubMed]

95. Cronin, J.R. Acid-labile amino acid precursors in the Murchison meteorite. II. A search for peptides and amino acyl amides. Orig. Life 1976, 7, 343-348. [CrossRef] [PubMed]

96. Engel, M.H.; Nagy, B. Distribution and enantiomeric composition of amino acids in the Murchison meteorite. Nature 1982, 296, 837-840. [CrossRef]

97. Engel, M.H.; Macko, S.A. Isotopic evidence for extraterrestrial non-racemic amino acids in the Murchison meteorite. Nature 1997, 389, 265-268. [CrossRef] [PubMed]

98. Bernstein, M.P.; Dworkin, J.P.; Sandford, S.A.; Cooper, G.W.; Allamandola, L.J. Racemic amino acids from the ultraviolet photolysis of interstellar ice analogues. Nature 2002, 416, 401-403. [CrossRef] [PubMed]

99. Muñoz Caro, G.M.; Meierhenrich, U.J.; Schutte, W.A.; Barbier, B.; Arcones Segovia, A.; Rosenbauer, H.; Thiemann, W.H.-P.; Brack, A.; Greenberg, J.M. Amino acids from ultraviolet irradiation of interstellar ice analogues. Nature 2002, 416, 403-406. [CrossRef] [PubMed]

100. Woon, D.E. Pathways to glycine and other amino acids in ultraviolet-irradiated astrophysical ices determined via quantum chemical modeling. Astrophys. J. 2002, 571, L177-L180. [CrossRef]

101. Elsila, J.E.; Dworkin, J.P.; Bernstein, M.P.; Martin, M.P.; Sandford, S.A. Mechanisms of amino acid formation in interstellar ice analogs. Astrophys. J. 2007, 660, 911-918. [CrossRef]

102. Förstel, M.; Bergantini, A.; Maksyutenko, P.; Góbi, S.; Kaiser, R.I. Formation of methylamine and ethylamine in extraterrestrial ices and their role as fundamental building blocks of proteinogenic $\alpha$-amino acids. Astrophys. J. 2017, 845, 1-12. [CrossRef]

103. Fuller, W.D.; Sanchez, R.A.; Orgel, L.E. Studies in prebiotic synthesis VI. Synthesis of purine nucleosides. J. Mol. Biol. 1972, 67, 25-33. [CrossRef]

104. Orgel, L.E. Prebiotic chemistry and the origin of the RNA world. Crit. Rev. Biochem. Mol. Biol. 2004, 39, 99-123. [PubMed]

(C) 2018 by the author. Licensee MDPI, Basel, Switzerland. This article is an open access article distributed under the terms and conditions of the Creative Commons Attribution (CC BY) license (http:/ / creativecommons.org/licenses/by/4.0/). 